\title{
4
}

\section{The Validity of Body Composition Measurement Using Dual Energy X-Ray Absorptiometry for Estimating Resting Energy Expenditure}

\author{
Chiyoko Usui ${ }^{1,2}$, Motoko Taguchi' ${ }^{3}$, \\ Kazuko Ishikawa-Takata ${ }^{4}$ and Mitsuru Higuchi ${ }^{5}$ \\ ${ }^{1}$ Department of Health Promotion and Exercise, \\ National Institute of Health and Nutrition, \\ ${ }^{2}$ Research Fellow of the Japan Society for the Promotion of Science, \\ 3Japan Women's College of Physical Education, \\ ${ }^{4}$ Department of Nutritional Education, \\ National Institute of Health and Nutrition, \\ ${ }^{5}$ Faculty of Sport Sciences, Waseda University, \\ Japan
}

\section{Introduction}

Tissue energy production varies over time, and for practical purposes, can be organized into three main components, resting energy expenditure (REE), the thermic effect of food, and the thermic effect of physical activity (Ravussin \& Bogardus, 1989). To maintain body weight, energy from food intake must equal energy expenditure. The energy requirement is defined as the average dietary energy intake that is predicted to maintain energy balance in healthy adults of a given age, gender, weight, height, and level of physical activity consistent with good health, and can be estimated from REE. REE reflects underlying tissue composition, mass, and metabolic activity (Elia, 1992) and accounts for $60-80 \%$ of total daily energy expenditure compared with the thermic effects of feeding and physical activity ( $\sim 10 \%$ and $\sim 15-30 \%$, respectively). The REE has a large impact on the regulation of body mass and energy balance. In the field of obesity research, the presence and genesis of between-individual REE differences is a topic of great interest. To date, some earlier studies demonstrated that body mass, especially fat-free mass (FFM), has been a useful candidate in estimating REE (Ravussin \& Bogardus, 1989; Fukagawa et al., 1990; Tataranni \& Ravussin, 1995). Therefore, it is important to accurately evaluate REE and to measure body composition by methods that are practical, precise, and accurate.

A strategy for exploring between-individual differences in REE is to apply a tissue organ prediction model (Elia, 1992; Wang et al., 2000; Gallagher et al., 1998 \& 2000). Each tissue and organ mass is quantified using either computed tomography (CT) or magnetic resonance imaging (MRI), and assigned assumed specific resting metabolic rates (Elia, 1992). The product of tissue organ mass and specific resting metabolic rate is then taken as the tissue organ REE, with the sum representing total body REE. 


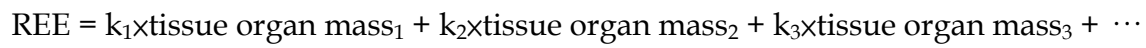

Dual-energy X-ray absorptiometry (DXA) can easily and accurately assess the body composition, including bone mineral content (BMC), fat mass (FM), and lean soft tissue mass (LST) of the whole body and the segments (Mazes et al., 1990; Svendsen et al., 1991 \& 1993). In addition, recent studies support the use of DXA as a means of providing a "metabolic map" for exploring between individual or group differences in observed REE values (Hunter et al., 2001; Hayes et al., 2002; Usui et al., 2009). Specifically, the LST of the arms and legs, as provided by regional DXA estimates, represents primarily lowmetabolic rate skeletal muscle tissue. In contrast, LST of the head and trunk includes all of the tissue organs with high metabolic rates, such as brain, heart, liver, kidneys, spleen, and gastrointestinal tract. Total body-fat estimates reflect low metabolic rate adipose tissue. The various regional and whole-body estimates thus provide a qualitative metabolic body composition map of high and low metabolic rate components. Hayes et al. (2002) demonstrated that REE can be estimated from five measured DXA values: body weight, total body fat mass, bone mineral content, appendicular lean mass, and head area. Their study showed that no bias was detected between measured and predicted REEs (Hayes et al., 2002). These results were quite good and support the overall concept that predictable relations exist between major tissue organ level components and heat production at rest. In view of the finding of Hayes et al. (2002), we improved the estimation model from the five component model to four component model (adipose tissue, skeletal muscle, bone, and residual tissue organs). It was also evaluated the possibility that measurement of the magnitude and distribution of fundamental somatic heat-producing units using DXA can be used to estimate REE in both young and elderly women with different aerobic fitness levels (Usui et al., 2009). We suggested that REE in adult women can be estimated from four tissue organ components by using DXA regardless of age and aerobic fitness levels.

On the other hand, the traditional REE estimation approach, now widely applied, is to link REE with body composition determinants using a two-compartment model consisting of FM and FFM (Wang et al., 2000). Empirical regression models are developed with REE set as the dependent variable, and age, race, sex, height, and weight (FFM and FM) set as potential predictor variables. The Harris-Benedict equation (Harris \& Benedict, 1919), Schofield equation (Schofield, 1985), and the Food and Agriculture Organization of the United Nations/World Health Organization/United Nations University (FAO/WHO/UNU) equation (FAO/WHO/UNU, 1985) are internationally used. In Japan, Dietary Reference Intakes for Japanese (DRI (Japan)) provides basal metabolic rate (BMR $\fallingdotseq \mathrm{REE}$ ) standards according to sex and age categories (Ministry of Heaith, Labour and Welfare of Japan, 2009). REE can be calculated as BMR standards multiplied by body weight. In addition, Ganpule et al. (2007) recently developed new predictive equations (NIHN (Japan)) for REE in Japanese.

In the present chapter, we evaluated the validity of body composition measurement using DXA for estimating REE. The REEs which are predicted by the equations of HarrisBenedict, Schofield, FAO/WHO/UNU, DRI (Japan), and NIHN (Japan) will then be crossvalidated against our measured and predicted values by using DXA. 


\section{Body composition analysis}

\subsection{Anthropometric measurements}

Body weight (BW) was measured to the nearest $0.1 \mathrm{~kg}$ by using an electronic scale (Inner Scan; Tanita Co., Japan and UC-321; A\&D Co., Ltd., Tokyo, Japan), and height (Ht) was measured to thenearest $0.1 \mathrm{~cm}$ by using a stadiometer (YL-65 and ST-2M; Yagami Inc., Japan). BW and Ht were measured with subjects wearing light clothing without shoes. Body mass index (BMI) was calculated by dividing BW in kilograms by the square of height in meters $\left(\mathrm{kg} / \mathrm{m}^{2}\right)$.

\subsection{Dual energy X-ray absorptiometry (DXA)}

The percentage of fat (\% body fat) and bone mineral content (BMC) of the whole body and appendicular lean soft tissue (LST) were measured by DXA (Hologic QDR-4500 DXA Scanner and Hologic QDT DXA Scanner; Hologic Inc., Whaltham, MA, USA). Fat-free mass (FFM) and fat mass (FM) were calculated by BW and \% body fat.

\subsection{Method for the calculation of tissue organ mass}

Tissue organ mass was calculated using the previously reported prediction model as follows. Bone mass (BM) was calculated by multiplying BMC times 1.85 (Snyder et al., 1975; Heymsfield et al., 1990). Adipose tissue mass (AT) was assumed to be $85 \%$ of total body fat (Heymsfield et al., 2002), leading to the model based on FM. Thus, AT was calculated by multiplying FM times 1.18. Skeletal muscle mass (SM) was calculated using the prediction model of Kim et al. (2002). Finally, residual mass (RM) was calculated as the difference between BW and the sum of the calculated BM, AT and SM. Residual mass includes all of the high-metabolic-rate tissues and organs such as heart, brain, liver, kidneys, spleen, and gastrointestinal tract.

$$
\begin{aligned}
& \mathrm{BM}(\mathrm{kg})=\mathrm{BMC}(\mathrm{g}) \times 1.85 / 1000 \\
& \mathrm{AT}(\mathrm{kg})=\mathrm{FM}(\mathrm{kg}) \times 1.18 \\
& \mathrm{SM}(\mathrm{kg})=1.13 \times \mathrm{LST}(\mathrm{kg})-0.02 \times \text { age }(\text { years })+0.97 \\
& \mathrm{RM}(\mathrm{kg})=\mathrm{BW}-(\mathrm{BM}+\mathrm{AT}+\mathrm{SM})
\end{aligned}
$$

\section{Resting energy expenditure (REE)}

\subsection{Method for measuring REE}

Participants came to the laboratory either on the previous night and stayed overnight, or came in the morning. In the latter case, subjects were asked to minimize any walking while en route from their home to the laboratory before REE determination. The measured REE (REEm) was directly measured by open-circuit indirect calorimetry. Measurements were performed between 0700 and $0900 \mathrm{~h}$ after 10-12 h of fasting, except for water, in a room at constant room temperature $\left(23-25^{\circ} \mathrm{C}\right)$. After entering the laboratory, subjects rested in the supine position for at least $30 \mathrm{~min}$, and a face mask was put on. In the case of overnight stay, the subjects were quietly awakened at 0630 and were attached a face mask while remaining in bed for 30 minutes. Two samples of expired air were collected in Douglas bags for a duration of $10 \mathrm{~min}$ each, and the mean value was used for the analysis. For young subjects, 
all measurements were made during the follicular phase of the menstrual cycle. An oxygen and carbon dioxide analyzer (Arco-1000A; Arco system, Japan and AE-300; Minato Medical Science, Tokyo) was used to analyze the rate of oxygen consumption and carbon dioxide production. The volume of expired air was determined using a dry gas volume meter (DC-5; Shinagawa, Japan) and converted to standard temperature, standard pressure and dry gas. Gas exchange results were converted to REE (kcal/day) using Weir's equation (Weir, 1949). To examine whether overnight stay before the REE measurement caused a significant difference in the observed REE, analysis of covariance with REE as the dependent variable and age, height, FFM, and FM as covariates was employed. No significant effect of the measurement conditions was observed (overnight stay: $1169 \pm 12 \mathrm{kcal} /$ day (mean \pm standard error (SE)), came in the early morning on the day: $1170 \pm 7 \mathrm{kcal} /$ day (mean $\pm \mathrm{SE}), \mathrm{F}$ $=0.001, \mathrm{p}=0.980)$.

\subsection{Method for estimating REE}

Estimation of REE using DXA was obtained based on the sum of four body compartments (BM, AT, SM and RM) times the corresponding tissue respiration rates as follows. The specific resting metabolic rate of the four compartments was assumed from previously reported data, bone $(2.3 \mathrm{kcal} / \mathrm{kg})$, AT $(4.5 \mathrm{kcal} / \mathrm{kg})$, skeletal muscle $(13 \mathrm{kcal} / \mathrm{kg})$ and residual (54 kcal/kg) (Holliday et al., 1967; Grande, 1989; Elia, 1992; Hayes et al., 2002; Heymsfield et al., 2002).

$$
\operatorname{REE}(\mathrm{kcal} / \text { day })=2.3 \times \mathrm{BM}+4.5 \times \mathrm{AT}+13 \times \mathrm{SM}+54 \times \mathrm{RM}
$$

\begin{tabular}{lcl}
\hline $\begin{array}{c}\text { Predictive equations } \\
\text { (kcal/day) }\end{array}$ & Age range & \\
\hline DXA & - & $2.3 \times \mathrm{BM}+4.5 \times \mathrm{AT}+13 \times \mathrm{SM}+54 \times \mathrm{RM}$ \\
Harris-Benedict & - & $655.0955+9.5634 \times \mathrm{BW}+1.8496 \times \mathrm{Ht}-4.6756 \times \mathrm{A}$ \\
Schofield & $18-29$ & $(0.062 \times \mathrm{BW}+2.036) \times 1000 / 4.186$ \\
& $30-59$ & $(0.034 \times \mathrm{BW}+3.538) \times 1000 / 4.186$ \\
& 60 over & $(0.038 \times \mathrm{BW}+2.755) \times 1000 / 4.186$ \\
FAO/WHO/UNU & $18-29$ & $(55.6 \times \mathrm{BW}+1397.4 \times \mathrm{Ht} / 100+146) / 4.186$ \\
& $30-59$ & $(36.4 \times \mathrm{BW}-104.6 \times \mathrm{Ht} / 100+3619) / 4.186$ \\
& 60 over & $(38.5 \times \mathrm{BW}+2665.2 \times \mathrm{Ht} / 100-1264) / 4.186$ \\
DRI (Japan) & $18-29$ & $22.1 \times \mathrm{BW}$ \\
& $30-49$ & $21.7 \times \mathrm{BW}$ \\
& 50 over & $20.7 \times \mathrm{BW}$ \\
NIHN (Japan) & - & $(0.0481 \times \mathrm{BW}+0.0234 \times \mathrm{Ht}-0.0138 \times \mathrm{A}-0.9708) \times 1000 / 4.186$ \\
\hline
\end{tabular}

BM: bone mass $(\mathrm{kg})$, AT: adipose tissue mass $(\mathrm{kg})$, SM: skeletal muscle mass $(\mathrm{kg}), \mathrm{RM}$ : residual mass (kg), BW: body weight $(\mathrm{kg}), \mathrm{Ht}$ : height (cm), A: age (years).

Table 1. Predictive equations of resting energy expenditure for women used in the present study. 


\subsection{Predictive equations of REE for women}

Other predictive REEs were calculated using the Harris-Benedict (Harris \& Benedict, 1919), Schofield (Schofield, 1985), FAO/WHO/UNU (FAO/WHO/UNU, 1985), DRI (Japan) (Ministry of Heaith, Labour and Welfare of Japan, 2009), and NIHN (Japan) (Ganpule et al., 2007) equations (Table 1).

\section{The validity of body composition measurement using DXA for estimating REE}

\subsection{Subjects}

The data used for the current analysis were collected from different 3 experimental studies that followed a similar methodology (Usui et al., 2009; Taguchi et al., 2011; Hasegawa et al., 2011). Total of 288 healthy women (216 young women; age: $21.8 \pm 2.0$ (18-29) years and 72 elderly women; age: $63.3 \pm 6.4$ (50-77) years) were recruited for the study. The elderly subjects had passed three years or more (13.5 \pm 7.4 years) after menopause. None had used medications that affect bone and estrogen replacement was eliminated from the analysis. All subjects were informed about the purpose and possible risks of the study and were then provided written informed consent. These studies were conducted according to the guidelines laid down in the Declaration of Helsinki. All procedures involving human subjects were approved by the Ethical Committee of the National Institute of Health and Nutrition in Tokyo, the Institutional Ethical Committee Review Board of Japan Women's College of Physical Education in Tokyo, and the Human Research Ethical Committee of the Faculty of Sport Sciences of Waseda University, in Saitama.

\subsection{Statistical analysis}

Results are presented as the mean \pm standard deviation (SD). Statistical analyses were carried out with the Sigma Stat 3.5 (Systat Software Inc., CA, USA). Statistical analysis was performed using the Student's t-test for parametric variables and the Mann-Whitney rank sum test for nonparametric variables to determine differences between young and elderly women. In addition to the mean \pm SD of the difference, total error was used to determine how accurately predicted REE matched measured REE. This statistic includes two sources of variation, one attributable to the lack of association between the two sets of measurement (standard error of estimate) and one attributable to the difference between the means (van der Ploeg et al., 2001). Statistical significance of differences between measured and predicted values in all subjects was analyzed by one-way repeatedmeasures analysis of variance (ANOVA) and Dunnett's post hoc test. Evaluation of bias between measured and predicted REE was conducted with a Bland-Altman analysis (Bland and Altman, 1986). Fixed bias was indicated if the 95\% coefficient interval (CI) for the difference between measured and predicted REE did not include zero. Predictive equations that are accurate display a tight prediction interval around zero. The $95 \% \mathrm{CI}$ below zero signify an underestimation, while the $95 \% \mathrm{CI}$ above zero signify an overestimation. The correlation of the difference between measured and predicted REE values and the mean from the both REE values was utilized to assess proportional bias. Statistical significance was set at $p<0.05$ for all predictors. 


\subsection{Results}

Table 2 presents the comparisons of subjects characteristics and body composition. Ht was significantly lower in the elderly women (50 over age group) than in young women (18-29 age group). However, no significant difference in BW was noted between two groups. The elderly women had significantly higher levels of \% body fat and FM, and lower levels of FFM than the young group. When the FFM was separated into BM, SM, and RM, young women had significantly higher BM, SM, and RM than elderly women.

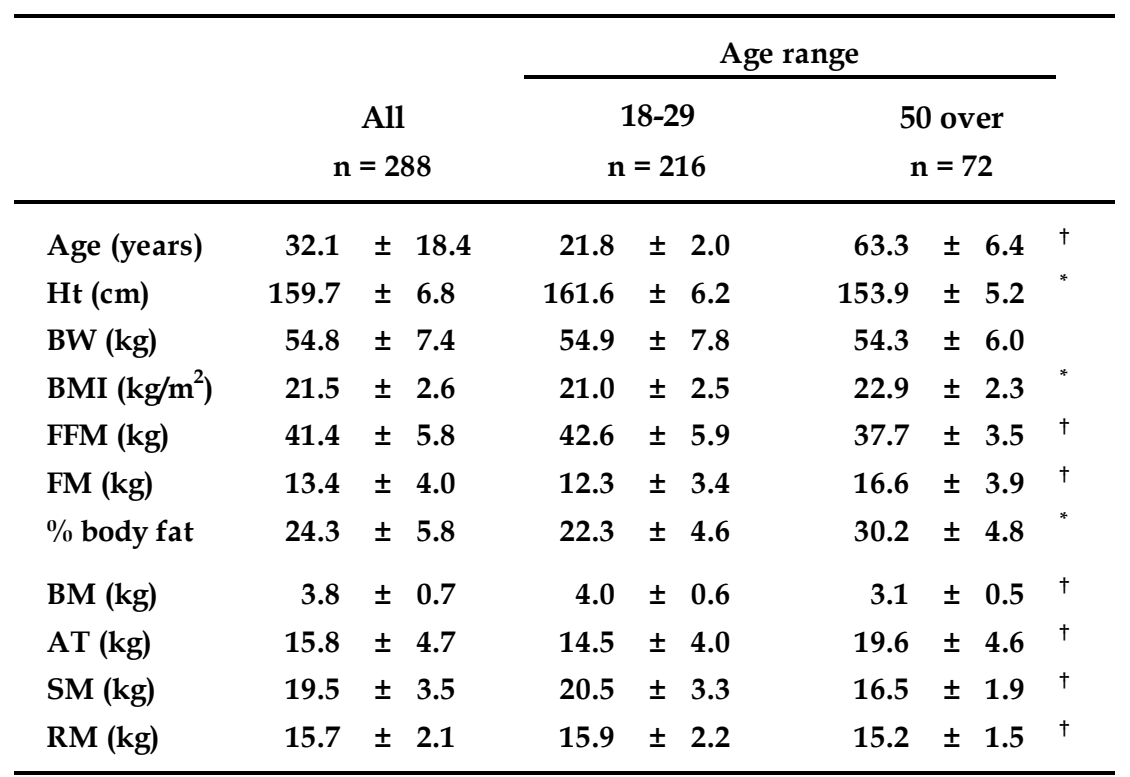

Means \pm SD, Ht: Height, BW: body weight, BMI: body mass index, FFM: fat-free mass, FM: fat mass, BM: bone mass, AT: adipose tissue mass, SM: skeletal muscle mass, RM: residual mass, * p<0.05 vs. 18 29 age group (Student's t-test), ${ }^{\dagger} \mathrm{p}<0.05$ vs. $18-29$ age group (Mann-Whitney rank sum test).

Table 2. Physical characteristics in the healthy women.

Table 3 show measured and predicted REEs, and the mean and total errors of predicted REEs. No significant differences were observed from the REEm in predicted REE values by using DXA, DRI (Japan) equation, and NIHN (Japan) equation in all subjects. On the other hand, the mean errors of REE predicted by the Harris-Benedict, Schofield, and $\mathrm{FAO} / \mathrm{WHO} / \mathrm{UNU}$ equations were significantly higher than the REEm in all subjects. Total error of estimated REE by using DXA was lowest in the group. Total error using NIHN (Japan) equation was the second to the lowest. In particular, total error of the HarrisBenedict equation was largest in healthy women.

The systemic bias between the measured and predicted REEs by the Bland-Altman analysis are shown in Table 4 and Fig. 1. Fixed bias was not present in only estimated REE by using DXA. However, the REE estimated by using DXA had a proportional bias (Fig. 1 (a)). Systematic bias (fixed and proportional bias) was presented in predicted REE by the HarrisBenedict, Schofield, FAO/WHO/UNU, and NIHN (Japan) equations. 


\begin{tabular}{|c|c|c|c|c|c|c|}
\hline \multirow{2}{*}{$\begin{array}{r}\text { All subjects } \\
(\mathrm{n}=288)\end{array}$} & \multicolumn{2}{|c|}{$\begin{array}{c}\text { REE } \\
\text { (kcal/day) }\end{array}$} & \multicolumn{2}{|c|}{$\begin{array}{r}\text { Mean error } \\
\text { (kcal/day) }\end{array}$} & \multicolumn{2}{|r|}{$\begin{array}{c}\text { Total error } \\
\text { (kcal/day) }\end{array}$} \\
\hline & 1170 & \pm 167 & & & & \\
\hline \multicolumn{7}{|l|}{ predicted REE } \\
\hline DXA & 1181 & \pm 152 & 11 & \pm 104 & & 105 \\
\hline Harris-Benedict & 1324 & \pm 123 & 154 & \pm 121 & c & 196 \\
\hline Schofield & 1273 & \pm 119 & 104 & \pm 111 & c & 151 \\
\hline FAO/WHO/UNU & 1281 & \pm 118 & 111 & \pm 109 & c & 156 \\
\hline DRI (Japan) & 1191 & \pm 166 & 22 & \pm 114 & & 115 \\
\hline NIHN (Japan) & 1184 & \pm 136 & 14 & \pm 110 & & 111 \\
\hline
\end{tabular}

Means \pm SD.; ${ }^{a}$ Mean error $=$ predicted REE - measured REE. $;{ }^{b}$ Total error $(\mathrm{kcal} /$ day $)=\sqrt{ }\left(\sum\right.$ (predicted $\mathrm{REE}$ - measured REE) ${ }^{2} / \mathrm{n}$ ). ; ${ }^{\mathrm{c}} \mathrm{p}<0.05$ vs. measured REE (one-way repeated-measures ANOVA and Dunnett's post hoc test).

Table 3. Measured and predicted REE and cross-validation of REE prediction equations against the measured REE of healthy women.

\begin{tabular}{|c|c|c|c|c|c|}
\hline \multirow[b]{3}{*}{ predicted REE } & \multicolumn{5}{|c|}{ Bland-Altman analysis } \\
\hline & \multirow{2}{*}{\multicolumn{2}{|c|}{$\frac{\text { fixed bias }}{95 \% \mathrm{CI}}$}} & \multicolumn{3}{|c|}{ proportional bias } \\
\hline & & & $\mathrm{r}$ & $p$ values & \\
\hline DXA & $-1.1 \sim 23.0$ & N.S. & -0.152 & $p=0.010$ & \\
\hline Harris-Benedict & $140.2 \sim 168.3$ & & -0.395 & $p<0.001$ & \\
\hline Schofield & $90.8 \sim 116.5$ & & -0.471 & $\mathrm{p}<0.001$ & \\
\hline FAO/WHO/UNU & $98.5 \sim 123.8$ & & -0.481 & $p<0.001$ & \\
\hline DRI (Japan) & $8.4 \sim 34.8$ & & -0.010 & $p=0.868$ & N.S. \\
\hline NIHN (Japan) & $1.6 \sim 27.2$ & & -0.307 & $p<0.001$ & \\
\hline
\end{tabular}

Table 4. Bland-Altman analysis.

\subsection{Discussion}

With the increasing availability of imaging methods, CT, MRI, and DXA, estimating methods of REE are developing and providing a "new" viewpoint of REE from the modeling perspective of organs and tissues. The importance of the developed approach is that it not only provides a qualitative estimate of REE, but of the actual distribution of heatproducing tissue components. As whole-body CT and MRI cannot assess body composition easily and quickly, previous investigators have explored the use of DXA as an available and practical alternative for developing qualitative tissue organ REE predictions. Hayes et al. (2002) demonstrated that REE can be estimated from five measured DXA values: body weight, total body fat mass, bone mineral content, appendicular lean mass, and head area. Their findings suggested that when REE is reviewed in the context of major heat-producing 


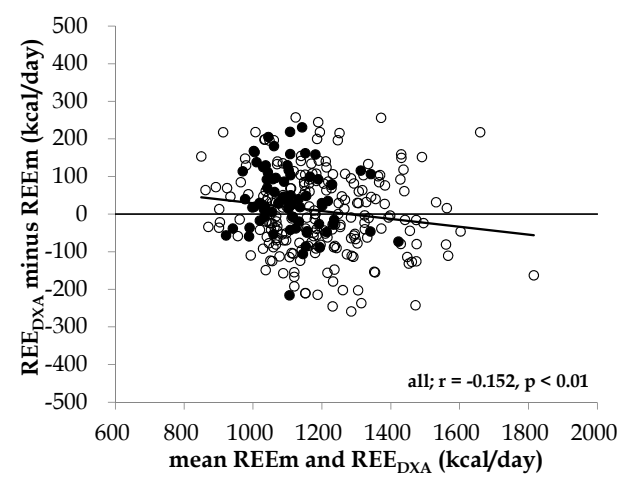

(a)

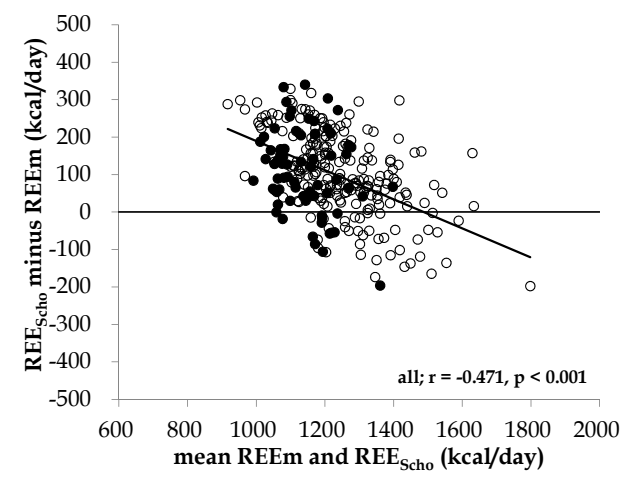

(c)

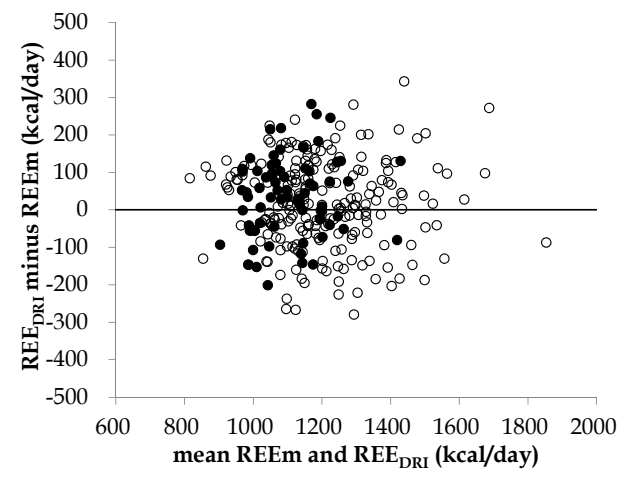

(e)

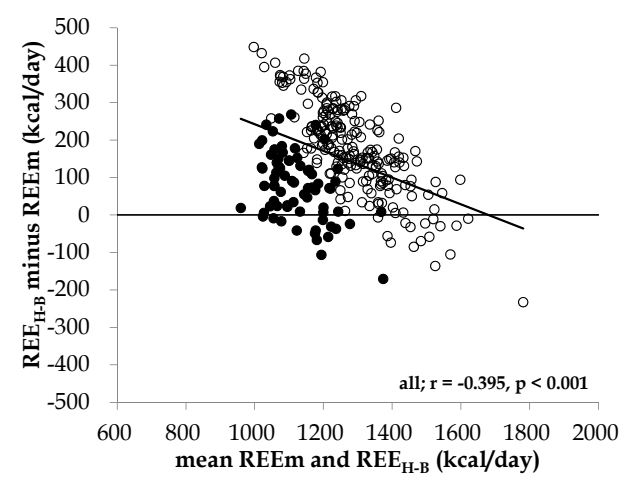

(b)

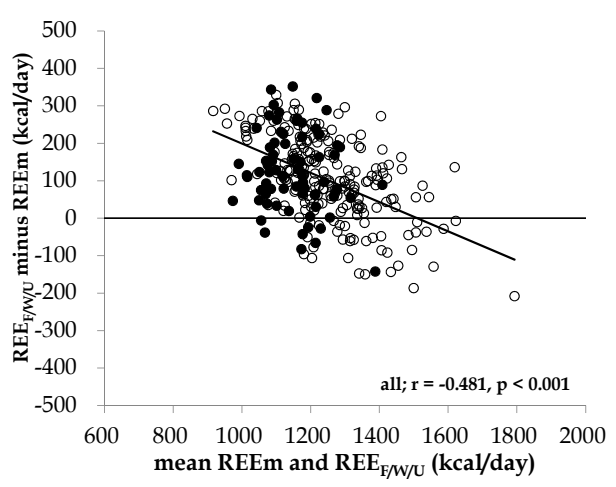

(d)

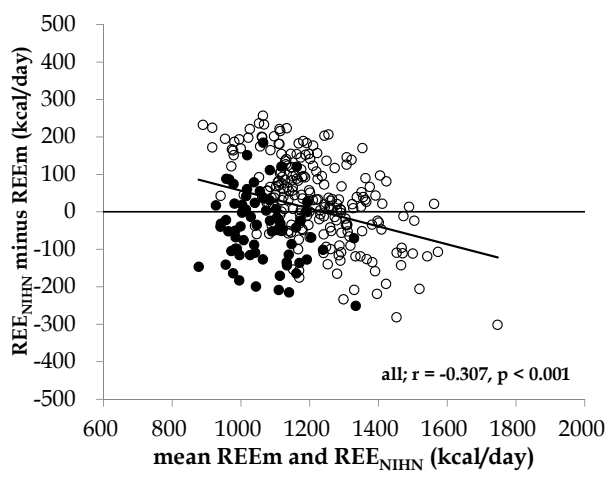

(f)

Plots of the differences between measured REE and predicted REE. Open circle $(\bigcirc)$ : young subjects $(\mathrm{n}=$ 216), black circle $(\mathbf{O})$ : elderly subjects $(n=72)$, the solid line $(-)$ : regression line in all subjects $(n=288)$, REEm: measured by expiratory gas exchange, REEDXA: estimated by using DXA, REEH-B: predicted by Harris-

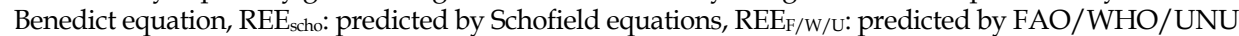
equations, REEDRI: predicted by DRI (Japan) equations, REENIHN: predicted by NIHN (Japan) equation.

Fig. 1. Bland-Altman plot. 
units differing in metabolic activity, normal-weight men and women are actually quite similar. In addition, this five component model allowed REE prediction over a wide range of FFM, because the mean REE prediction errors in intermediate weight, underweight and obese subjects were not significantly different between groups (Bosy-Westphal et al., 2004). These findings provided indirect evidence for a view that, for practical purposes within humans, the specific metabolic rate is constant with increasing organ mass, and that interindividual REE differences in under- or overweight are more a reflection of an altered ratio of organ-tissue mass to body size.

On the other hand, there is evidence that REE is lower in the elderly, even after adjustment for tissue and organ mass (Gallagher et al., 2000) or age-related differences in body composition (Van Pelt et al., 1997, 2001). This raises the important question of the validity of assumed tissue- and organ-specific metabolic rates. The specific metabolic rates applied in the present study represent literature averages. The extent to which these heat production rates are valid remains unknown. Moreover, the specific metabolic rates for some components reported in the literature vary widely. However, we demonstrated that estimation based on the four tissue organs by using DXA allows successful calculation of REE in female adults regardless of age and aerobic fitness levels. (Usui et al., 2009). Our findings suggested the possibility that REE is regulated mainly by the mass of the tissue organs with lower and higher metabolic rates, including skeletal muscle and intestinal organs, rather than a decline in the specific metabolic rate of different tissue organs associated with advancing age and decreasing aerobic fitness levels in young and elderly women.

In addition, as for the four component model of REE prediction, Taguchi et al. (2011) evaluated that the relationship between REE and body composition in Japanese female athletes with a wide range of body sizes. Their results indicated, in good agreement with previous study (Bosy-Westphal et al., 2004), that REE for female athletes with a wide range of body sizes can be attributed to changes in organ tissue mass, and not changes in organ tissue metabolic rate. Moreover, Hasegawa et al. (2011) investigated the differences in body composition and REE between young women with low $\left(\mathrm{BMI}<18.5 \mathrm{~kg} / \mathrm{m}^{2}\right)$ and normal BMI $\left(18.5 \leqq \mathrm{BMI}<25 \mathrm{~kg} / \mathrm{m}^{2}\right)$, and suggested the possibility that low BMI subjects with normal menstrual cycle do not have any differences in specific metabolic rates of different tissue organs compared to those with normal BMI. According to Bland-Altman analysis in the present chapter, although there is a proportional bias in estimation of REE by using DXA, this proportional bias is relatively small compared with other estimation methods for REE (Table 4 and Fig. 1). Furthermore, fixed bias was not present in only estimated REE by using DXA. These findings suggested that estimation of the four tissue organs by using DXA can easily, practically, precisely, and accurately predict REE in healthy men and women.

The present chapter also focused on the validity of body composition measurement using DXA for estimating REE. Our results showed that predicted REE values by using DXA, DRI (Japan) equations, and NIHN (Japan) equation were not significantly different from the REEm, while Harris-Benedict, Schofield, and FAO/WHO/UNU equations significantly higher than the REEm in healthy women (Table 3). DRI (Japan) and NIHN (Japan) equations were developed based on the data for Japanese subjects with standard body size (Ministry of Heaith, Labour and Welfare of Japan, 2009; Ganpule et al., 2007). Schofield and $\mathrm{FAO} / \mathrm{WHO} / \mathrm{UNU}$ equations were developed based on data from a population of many 
races (Schofield, 1985; FAO/WHO/UNU, 1985). However, the data used to develop the Schofield equations were mostly from young European military and police recruits with $45 \%$ being of Italian descent. Harris-Benedict equation was developed using data obtained in healthy normal weight Caucasian men and women aged 15-74 years. Asians are reported to have lower REE than Europeans by 10-12\% (Hayter et al., 1994), even after adjustment for body composition. According to a recent study by Miyake et al. (2011), mean difference and total error values were smaller using the DRI (Japan) equations and NIHN (Japan) equation than the internationally used equations (Harris-Benedict, Schofield, FAO/WHO/UNU) in both sexes. In particular, the total error was lower for the NIHN (Japan) equation than the other equations in most age groups (Miyake et al., 2011). In the present chapter, the mean errors of the predicted REEs by using DXA, DRI (Japan) equations, and NIHN (Japan) equation were smaller than those of internationally used equations in all subjects (Table 3). In addition, total error of estimated REE by using DXA, DRI (Japan) equations, and NIHN (Japan) equation were also lower than other total errors (105 kcal/day, $115 \mathrm{kcal} /$ day, 111 $\mathrm{kcal} /$ day, respectively). Moreover, while these three prediction methods had some kind of bias, the bias was relatively small compared with other internationally used equations (Table 4 \& Fig. 1 (a), (e), (f)). The results of this chapter supported the notions that the DRI (Japan) and NIHN (Japan) equations of REE are more accurate in healthy Japanese subjects, and that estimating REE from four tissue organ components by using DXA will be one of the useful methods for the dietary management (energetic assessment) in healthy Japanese subjects.

Our investigation has a few limitations. First, we did not test middle-aged (30-49 years) and very old (> 80 years) women and the adult men of all ages. It is unclear whether age-related functional decline in cells or tissue organs make a major impact on the heat production. Second, it was performed only in a Japanese population. Hayter et al. (1994) reported that Asians have lower REE than Europeans by 10-12\%, even after adjustment for body composition. Third, because all the participants were healthy adult women, little is known as to whether this four component model for estimating REE by using DXA can accurately estimate REE in patients with a chronic disease, such as diabetes mellitus or cardiac disorder. Recently, DXA and regression modeling of REE showed that skeletal muscle is hypermetabolic in patients with HIV lipoatrophy (Kosmiski et al., 2009). Accordingly, the specific metabolic rate of each tissue organ may differ from those in healthy adults over 80 years of age, other ethnic subjects, or patients with a chronic disease. Future studies are needed to extend these observations and to analyze gender-related, genetics, hormonal, ethnic, and other determinant factors of REE.

\section{Conclusion}

The results of the present chapter suggest that REE in healthy adult women can be accurately estimated from four tissue organ components by using DXA, because the mean error, total error, and systematic bias between the predicted and measured REE was relatively small compared with other estimation methods for REE. Therefore, we expect that the DXA will be one of the useful methods not only for examining body composition and bone mineral density but also for estimating REE in a broad range of fields. In the future, DXA method may offer a bridge to effective prevention, treatment and care with the dietary management and exercise regimen for life style-related disease, such as obesity, osteoporosis, and type 2 diabetes. 


\section{Acknowledgments}

We express our appreciation to the subjects for their cooperation in this study. We thank the members of the National Institute of Health and Nutrition and Waseda University for their help in this experiment. This study was supported by a Research Grant for Academic Frontier Projects from the Ministry of Education, Culture, Sports, Science and Technology (05F-02), a Waseda University Grant for Special Research Projects (2005A-932, 2006B-242), Health Sciences Research Grants from the Ministry of Health, Labor and Welfare, Medical Health Care Research Grants from the Consolidated Research Institute for Advanced Science and Medical Care at Waseda University, Research grant for Waseda University Global COE program: Sports Sciences for Promotion of Active Life (projectsIII-2), Research Grant from Japan Women's College of Physical Education, and Research Grants from the Japanese Olympic Committee.

\section{References}

Bland, J.M. \& Altman, D.G. (1986). Statistical methods for assessing agreement between two methods of clinical measurement. The Lancet, Vol.327, No.8476, (08 February 1986), pp. 307-310, Print ISSN 0140-6736

Bosy-Westphal, A.; Reinecke, U.; Schlörke, T.; Illner, K.; Kutzner, D.; Heller M. \& Müller, M.J. (2004). Effect of organ and tissue masses on resting energy expenditure in underweight, normal weight and obese adults. International Journal of Obesity and Related Metabolic Disorders, Vol.28, No.1, (January 2004), pp. 72-79, Print ISSN 03070565, Online ISSN 1476-5497

Elia, M. (1992). Organ and tissue contribution to metabolic rate. In: Energy Metabolism: Tissue Determinants and Cellular Corollaries, Kinney, J. M. \& Tucker, H. N. (eds), pp. 61-80, Raven Press, ISBN 978-088-1678-71-0, New York

FAO/WHO/UNU. (1985). Energy and protein requirements, report of a joint FAO/WHO/UNU expert consultation. Technical Report Series 724, WHO, ISBN 92-4-120724-8, Geneva.

Fukagawa, N.K.; Bndini, L.G. \& Young, J.B. (1990). Effect of age on body composition and resting metabolic rate. American Journal of Physiology Endocrinology and Metabolism, Vol.259, No.2, (August 1990), pp. E233-E238, Print ISSN 0193-1849, Online ISSN 1522-1555

Gallagher, D.; Belmonte, D.; Deurenberg, P.; Wang, Z.; Krasnow, N.; Pi-Sunyer, F.X. \& Heymsfield S.B. (1998). Organ-tissue mass measurement allows modeling of REE and metabolically active tissue mass. American Journal of Physiology Endocrinology and Metabolism, Vol.275, No.2, (August 1998), pp. E249-E258, Print ISSN 0193-1849, Online ISSN 1522-1555

Gallagher, D.; Allen, A.; Wang, Z.; Heymsfield, S.B. \& Krasnow, N. (2000). Smaller organ tissue mass in the elderly fails to explain lower resting metabolic rate. Annals of the New York Academy of Sciences, Vol.904, (May 2000), pp. 449-455, Print ISSN 00778923, Online ISSN 1749-6632

Ganpule, A.A.; Tanaka, S.; Ishikawa-Takata, K. \& Tabata, I. (2007). Interindividual variability in sleeping metabolic rate in Japanese subjects. European Journal of Clinical Nutrition, Vol.61, No.11, (Epub February 2007), pp. 1256-1261, Print ISSN 0954-3007, Online ISSN 1476-5640 
Grande, F. (1980). Energy expenditure of organs and tissues. In: Assessment of Energy Metabolism in Health and Disease: Report of the First Ross Conference on Medical Research, Kinney, J.M. (ed.), pp. 88-92, Ross Laboratories, Columbus, Ohio

Harris, J.A. \& Benedict, F.G. (1919). A Biometric Study of Basal Metabolism in Man, Washington, Publication, No. 279, Carnegie Institute of Washington, ISBN 978-1144176-76-9, Washington D.C.

Hasegawa, A.; Usui, C.; Kawano, H.; Sakamoto, S. \& Higuchi, M. (2011). Characteristics of body composition and resting energy expenditure in lean young women. Journal of Nutritional Science and Vitaminology, Vol.57, No.1, (January 2011), pp. 74-79, Print ISSN 0301-4800, Online ISSN 1881-7742

Hayes, M.; Chustek, M.; Wang, Z.; Gallagher, D.; Heshka, S.; Spungen, A.; Bauman, W. \& Heymsfield S.B. (2002). DXA: potential for creating a metabolic map of organ-tissue resting energy expenditure components. Obesity Research, Vol.10, No.10, (October 2002), pp. 969-977, ISSN 1930-7381, Online ISSN 1930-739x

Hayter, J.E. \& Henry, C.J.K. (1994). A re-examination of basal metabolic rate predictive equations: the importance of geographic origin of subjects in sample selection. European Journal of Clinical Nutrition, Vol.48, No.10, (October 1994), pp. 702-707, Print ISSN 0954-3007, Online ISSN 1476-5640

Heymsfield, S.B.; Smith, R.; Aulet, M.; Bensen, B.; Lichtman, S.; Wang, J. \& Pierson, RN. (1990). Appendicular skeletal muscle mass: measurement by dualphoton absorptiometry. American Journal of Clinical Nutrition, Vol.52, No.2, (August 1990), pp. 214-218, Print ISSN 0002-9165, Online ISSN 1938-3207

Heymsfield, S.B.; Gallagher, D.; Kotler, D.P.; Wang, Z.; Allison, D.B. \& Heshka, S. (2002). Body-size dependence of resting energy expenditure can be attributed to nonenergetic homogeneity of fat-free mass. American Journal of Physiology Endocrinology and Metabolism, Vol.282, No.1, (January 2002), pp. E132-E138, Print ISSN 0193-1849, Online ISSN 1522-1555

Holliday, M.A.; Potter, D.; Jarrah, A. \& Bearg, S. (1967). The relation of metabolic rate to body weight and organ size. Pediatric Research, Vol.1, No.3, (May 1967), pp. 185195, Print ISSN 0031-3998, Online ISSN 1530-0447

Hunter, G.R.; Weinsier, R.L.; Gower, B.A. \& Wetzstein, C. (2001). Age-related decrease in resting energy expenditure in sedentary white women: effects of regional differences in lean and fat mass. American Journal of Clinical Nutrition, Vol.73, No.2, (February 2001), pp. 333-337, Print ISSN 0002-9165, Online ISSN 1938-3207

Kim, J.; Wang, Z.; Heymsfield, S.B.; Baumgartner, R.N. \& Gallagher, D. (2002). Total-body skeletal muscle mass: estimation by a new dual-energy X-ray absorptiometry method. American Journal of Clinical Nutrition, Vol.76, No.2, (August 2002), pp. 378383, Print ISSN 0002-9165, Online ISSN 1938-3207

Kosmiski, L.A.; Ringham, B.M.; Grunwald, G.K. \& Bessesen, D.H. (2009). Dual-energy X-ray absorptiometry modeling to explain the increased resting energy expenditure associated with the HIV lipoatrophy syndrome. American Journal of Clinical Nutrition, Vol.90, No.6, (December 2009), pp. 1525-1531, Print ISSN 0002-9165, Online ISSN 1938-3207

Mazes, R.B.; Barden, H.S.; Bisek, J.P. \& Hanson J. (1990). Dual energy x-ray absorptiometry for total-body and regional bone-mineral and soft-tissue composition. American 
Journal of Clinical Nutrition, Vol.51, No.6, (June 1990), pp. 1106-1112, Print ISSN 0002-9165, Online ISSN 1938-3207

Ministry of Heaith, Labour and Welfare of Japan. (2009). Dietary reference intakes for Japanese, 2010, Daiichi Shuppan, ISBN 978-4-8041-1219-0, Tokyo. (in Japanese)

Miyake, R.; Tanaka, S.; Ohkawara, K.; Ishikawa-Takata, K., Hikihara Y.; Taguri, E.; Kayashita J. \& Tabata, I. (2011). Validity of predictive equations for basal metabolic rate in Japanese adults. Journal of Nutritional Science and Vitaminology, Vol.57, No.3 , (June 2011), pp. 224-232, Print ISSN 0301-4800, Online ISSN $1881-7742$

Ravussin, E. \& Bogardus, C. (1989). Relationship of genetics, age, and physical fitness to daily energy expenditure and fuel utilization. American Journal of Clinical Nutrition, Vol.49, No.5 supplements, (May 1989), pp. S968-S975, Print ISSN 0002-9165, Online ISSN 1938-3207

Schofield, W.N. (1985). Predicting basal metabolic rate, new standards and review of previous work. Human Nutrition. Clinical Nutrition, Vol.39, supplements, (1985), pp. 5-41, ISSN 0263-8290

Snyder, W.S.; Cook, M.J.; Nasset, E.S.; Karhausen, L.R.; Howells, G.P. \& Tipton, I.H. (1975). Report of the Task Group of Reference Man, Pergamon Press, ISBN 00-8-017024-2, Oxford.

Svendsen, O.L.; Haarbo, J.; Heitman, B.L.; Gotfredsen, A. \& Christiansen, C. (1991). Measurement of body fat in elderly subjects by dual energy x-ray absorptiometry, bioelectrical impedance, and anthropometry. American Journal of Clinical Nutrition, Vol.53, No.5, (May 1991), pp. 1117-1123, Print ISSN 0002-9165, Online ISSN 19383207

Svendsen, O.L.; Haarbo, J.; Hassager, C. \& Christiansen, C. (1993). Accuracy of measurements of body composition by dual energy x-ray absorptiometry in vivo. American Journal of Clinical Nutrition, Vol.57, No.5, (May 1993), pp. 605-608, Print ISSN 0002-9165, Online ISSN 1938-3207

Taguchi, M.; Ishikawa-Takata, K.; Tatsuta, W.; Katsuragi, C.; Usui, C.; Sakamoto, S. \& Higuchi M. (2011). Resting energy expenditure can be assessed by fat-free mass in female athletes regardless of body size. Journal of Nutritional Science and Vitaminology, Vol.57, No.1, (January 2011), pp. 22-29, Print ISSN 0301-4800, Online ISSN 1881-7742

Tataranni, P.A. \& Ravussin, E. (1995). Variability in metabolic rate: biological sites of regulation. International Journal of Obesity and Related Metabolic Disorders, Vol.19, No.4 supplements, (October 1995), pp. S102-S106, Print ISSN 0307-0565, Online ISSN 1476-5497

Usui, C.; Takahashi, E.; Gando, Y.; Sanada, K.; Oka, J.; Miyachi, M.; Tabata, I. \& Higuchi, M. (2009). Resting energy expenditure can be assessed by dual-energy X-ray absorptiometry in women regardless of age and fitness. European Journal of Clinical Nutrition, Vol.63, No.4, (Epub February 2008), pp. 529-535, Print ISSN 0954-3007, Online ISSN 1476-5640

van der Ploeg, G.E.; Gunn, S.M.; Withers, R.T.; Modra, A.C.; Keeves, J.P. \& Chatterton, B.E. (2001). Predicting the resting metabolic rate of young Australian males. European Journal of Clinical Nutrition, Vol.55, No. 3, (March 2001), pp. 145-152, Print ISSN 0954-3007, Online ISSN 1476-5640 
Van Pelt, R.E.; Dinneno, F.A.; Seals, D.R. \& Jones, P.P. (2001). Age-related decline in RMR in physically active men: relation to exercise volume and energy intake. American Journal of Physiology Endocrinology and Metabolism, Vol.281, No.3, (September 2001), pp. E633-E639, Print ISSN 0193-1849, Online ISSN 1522-1555

Van Pelt, R.E.; Jones, P.P.; Davy, K.P.; Desouza, C.A.; Tanaka, H.; Davy, B.M. \& Seals D.R. (1997). Regular exercise and the age-related decline in resting metabolic rate in women. The Journal of Clinical Endocrinology and Metabolism, Vol.82, No.10, (October 1997), pp. 3208-3212, Print ISSN 0021-972x, Online ISSN 1945-7197

Wang, Z.; Heshka, S.; Gallagher, D.; Boozer, C.N.; Kotler, D.P. \& Heymsfield, S.B. (2000). Resting energy expenditure fat-free mass relationship: new insights provided by body composition modeling. American Journal of Physiology Endocrinology and Metabolism, Vol.279, No.3, (September 2000), pp. E539-E545, Print ISSN 0193-1849, Online ISSN 1522-1555

Weir, J.B. (1949). New methods for calculating metabolic rate with special reference to protein metabolism. Journal of Physiology, Vol.109, No.1-2, (August 1949), pp. 1-9, Print ISSN 0022-3751, Online ISSN 1469-7793 


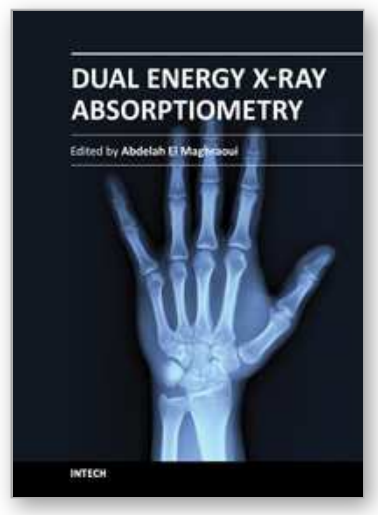

\author{
Dual Energy X-Ray Absorptiometry \\ Edited by Prof. Abdelah El Maghraoui
}

ISBN 978-953-307-877-9

Hard cover, 146 pages

Publisher InTech

Published online 25, January, 2012

Published in print edition January, 2012

The World Health Organization (WHO) has established dual-energy x-ray absorptiometry (DXA) as the best densitometric technique for assessing bone mineral density (BMD) in postmenopausal women and has based the definitions of osteopenia and osteoporosis on its results. DXA enables accurate diagnosis of osteoporosis, estimation of fracture risk and monitoring of patients undergoing treatment. Additional features of DXA include measurement of BMD at multiple skeletal sites, vertebral fracture assessment and body composition assessment, including fat mass and lean soft tissue mass of the whole body and the segments. This book contains reviews and original studies about DXA and its different uses in clinical practice (diagnosis of osteoporosis, monitoring of BMD measurement) and in medical research in several situations (e.g. assessment of morphological asymmetry in athletes, estimation of resting energy expenditure, assessment of vertebral strength and vertebral fracture risk, or study of dry bones such as the ulna).

\title{
How to reference
}

In order to correctly reference this scholarly work, feel free to copy and paste the following:

Chiyoko Usui, Motoko Taguchi, Kazuko Ishikawa-Takata and Mitsuru Higuchi (2012). The Validity of Body Composition Measurement Using Dual Energy X-Ray Absorptiometry for Estimating Resting Energy Expenditure, Dual Energy X-Ray Absorptiometry, Prof. Abdelah El Maghraoui (Ed.), ISBN: 978-953-307-877-9, InTech, Available from: http://www.intechopen.com/books/dual-energy-x-ray-absorptiometry/the-validity-ofbody-composition-measurement-using-dual-energy-x-ray-absorptiometry-for-estimating-r

\section{INTECH}

open science | open minds

\section{InTech Europe}

University Campus STeP Ri

Slavka Krautzeka 83/A

51000 Rijeka, Croatia

Phone: +385 (51) 770447

Fax: +385 (51) 686166

www.intechopen.com

\section{InTech China}

Unit 405, Office Block, Hotel Equatorial Shanghai

No.65, Yan An Road (West), Shanghai, 200040, China

中国上海市延安西路65号上海国际贵都大饭店办公楼405单元

Phone: +86-21-62489820

Fax: $+86-21-62489821$ 
(C) 2012 The Author(s). Licensee IntechOpen. This is an open access article distributed under the terms of the Creative Commons Attribution 3.0 License, which permits unrestricted use, distribution, and reproduction in any medium, provided the original work is properly cited. 